\title{
Improvement in the Growth and Yield of Kalmegh influenced by Pruning and Nutrition levels
}

\author{
J. Cheena $^{1 *}$, V. Krishna Veni ${ }^{1}$, M. Padma ${ }^{2}$ and M. Sreenivas ${ }^{3}$ \\ ${ }^{1}$ Medicinal and Aromatic Plant Research Station, Rajendranagar, Hyderabad, \\ ${ }^{2}$ Department of Horticulture, Mulugu, Siddipet, India \\ ${ }^{3}$ Department of Horticulture, Mojerla, Wanaparthy, Sri Konda Laxman Telangana State \\ Horticultural University, Mulugu(V\& M), Siddipet dist., Telangana, India \\ *Corresponding author
}

\section{A B S T R A C T}

\section{Keywords}

Kalmegh, pruning, herbage yield, nutrition levels, seed yield

\section{Article Info}

Accepted:

25 November 2020

Available Online:

10 December 2020
An investigation was carried out at Medicinal and Aromatic Plant Research Station Rajendranagar, Sri Konda Laxman Telangana State Horticultural University, Mulugu (V \& M), Siddipet Dist., Telangana State during the period of 2017-20 to determine the Improvement in the growth and yield of kalmegh influenced by pruning and nutrition levels. The study was conducted with the different levels of pruning i.e, $\mathrm{P}_{1^{-}} 0$ Pruning, $\mathrm{P}_{2^{-}}$Pruning once at 6 weeks after sowing, $\mathrm{P}_{3}$ - Pruning twice at 6 and 8 weeks after sowing and different sources of Nutrition i.e, $\mathrm{N}_{1}-75: 75: 50$ NPK ha ${ }^{-1}+$ FYM 10 t/ha, $\mathrm{N}_{2}-100: 75: 50 \mathrm{NPK}^{-1} \mathrm{ha}^{-1}+$ FYM 5 t/ha, $\mathrm{N}_{3}-100: 75: 50$ NPK ha ${ }^{-1}+$ Vermicompost 2.5t/ha. The parameters in terms of fresh herbage yield, seed yield were significantly differed with respect to the different pruning and nutrition sources. The maximum plant height $(56.56 \mathrm{~cm})$, no. of branches (23.12), fresh herbage yield (65.42 q/ha), dry herbage yield (23.62 $\mathrm{q} / \mathrm{ha}$ ) and seed yield $(1.98 \mathrm{q} / \mathrm{ha})$ were found in $\mathrm{P}_{3} \mathrm{~N}_{3}$ while the minimum plant height, no. of branches, fresh herbage yield, dry herbage yield and seed yield were found in $\mathrm{P}_{1} \mathrm{~N}_{1}$.

\section{Introduction}

Kalmegh (Andrographis paniculata Nees) known as 'King of bitters' belonging to the family Acanthaceae, is an erect annual herb indigenous to India and cultivated in many parts of Asia (Kumar et al., 2012). In India it is widely cultivated in the tropical and moist regions, including Uttar Pradesh (Patidar et al., 2011). The genus Andrographis is of particular significance in India, as 25 out of 28 species occur in the Indian subcontinent only. Kalmegh is one of the most important medicinal plant, known for its preventive and curative properties. The fresh and dried leaves of kalmegh and juice extracted from herb are 
official drugs in Indian pharmacopoeia. In Thailand, the decoction of the dried leaf is used against high blood pressure. It forms the principle ingredient of household medicine called "Alui", extensively used in West Bengal. Common ayurvedic drugs are "Kalmeghasava" and "Kalmeghnamayas Haub" (Sanjutha et al., 2008). In India, the entire plant is used to obtain andrograpolide (Randa and Sharma, 1990). A. paniculata is an important source of diterpenoids, the most important one being andrographolide (Arpana and Bagyaraj 2007). The above ground parts of A. paniculata, particularly the leaves contain the higher concentrations of the pharmacologically active chemical constituents (Jarukamjorn and Nemoto 2008; Akbar 2011).

The leaves contain the maximum andrographolide $(2.5 \%)$, while the stem contains lesser amount $(2.0 \%)$ of this active principle (Chakravarti and Chakravarti, 1952 Moktader and Sirchar, 1939). Pruning is an important cultural practice that has been shown to enhance both productivity and quality of plant. A study by Yilmaz et al., (2004) on tea shown that pruning affected the composition and quality of tea leaves. Calatayud et al., (2008) reported that pruned plant has higher capacity to promote the photosynthetic light reaction, a large number of metabolic sinks and a higher turgor pressure compared to unpruned plant. If plants are pruned the starch reserves in the roots are utilized for shoot growth to maintain equilibrium (Zeing, 2003). Nutrient management is critical issue that determine quantity and quality of harvested produce. Nishchitha et al., (2018) reported that with the application of 100:75:50 kg NPK per ha + Azatobacter (1 q) enriched in FYM (5 t ha-1) + vermicompost $1 \mathrm{t}$ per ha the yield and quality of kalmegh has increased and with no significant variation in andrographolide content in plants. Pruning and sources of nutrition affects the growth and yield of the plant therefore, the present investigation was carried out.

\section{Materials and Methods}

The experiment entitled "Improvement in the growth and yield of Kalmegh influenced by Pruning and Nutrition levels" was carried out for three years (2017-2020) at Medicinal and Aromatic Plant Research Station Rajendranagar, SKLTSHU, Mulugu, Siddipet district. The meteorological data was collected from the Agricultural Research Institute, Rajendranagar for the experimental period of three years (2017-2020). It comes under sub tropical zone and is situated at latitude of $17^{0} 30^{1} \mathrm{~N}$ and longitude of $78^{0} 42^{1} \mathrm{E}$. It was normal weather data on total rainfall, maximum and minimum temperature, relative humidity, that prevailed during the period of experimentation. The land used under the experimental layout was red with good drainage and low water holding capacity with uniform texture. The soil characteristics were, $\mathrm{pH} 7.20$, electrical conductivity $0.67 \mathrm{dSm}-1$, organic carbon $0.32 \%$, Available Nitrogen 120 $\mathrm{kg} / \mathrm{ha}$, Available Phosphorus $48 \mathrm{~kg} / \mathrm{ha}$ and Available Potassium $60 \mathrm{~kg} / \mathrm{ha}$. Good soil fertility management ensures adequate nutrient availability to plant and improve their growth.

The experiment was designed in Factorial Randomised Block Design with three replications with the spacing of $30 * 30 \mathrm{~cm}$. Complete dosage of farmyard manure and vermicompost were applied at the time of final ploughing. Nitrogen, Phosphorus and Potassium were applied in the form of Urea, Single super phosphate and Murate of potash respectively. Nitrogen was applied in three split doses, before transplanting add $50 \%$ of Nitrogen and full dose of phosphorous and potassium to the field, remaining $50 \%$ of Nitrogen was applied as top dressing at 6 and 8 weeks after sowing i.e, after $1^{\text {st }}$ and $2^{\text {nd }}$ pruning. The plant height was recorded before each harvest from ground level to the tip of 
plant with the help of measuring tape and was expressed in centimeters $(\mathrm{cm})$. Fresh herbage yield was estimated by harvesting the crop with sickle $15 \mathrm{~cm}$ above the ground level and immediately weighted for obtaining plot yield. Then plot yield was transformed to yield per hectare which was expressed in terms of quintals. After recording the fresh herbage yield, the plants were placed under shade for 4-5 days and obtained dry herbage yield which was again expressed in terms of quintals and then seeds are collected by threshing to obtain seed yield.

\section{Results and Discussion}

The plant height was significantly influenced by pruning and nutrition levels at all stages of crop growth (Table 1). Pruning twice at 6 and 8 weeks after sowing showed maximum plant height $(44.25 \mathrm{~cm})$. During initial stages of crop, nutrients are readily available through inorganic fertilizers, whereas during later stages of crop the nutrients are supplied by both inorganic as well as organic forms due to decomposition, thus making higher availability of nutrients. Moreover the nutrient concentration of vermicompost is higher when compared to FYM and hence highest plant height $(43.58 \mathrm{~cm})$ was recorded with application of 100:75:50 NPK ha ${ }^{-1}+$ Vermicompost 2.5t/ha. The interaction effect of pruning and nutrition levels showed significant variation on plant height.

The highest plant height $(52.34 \mathrm{~cm})$ was recorded with pruning twice at 6 and 8 weeks after sowing and application of 100:75:50 NPK ha ${ }^{-1}+$ vermicompost 2.5t/ha $\left(\mathrm{P}_{3} \mathrm{~N}_{3}\right)$ which was on par (48.19) with pruning twice at 6 and 8 weeks after sowing and application of 100:75:50 NPK ha ${ }^{-1}+$ FYM 5t/ha $\left(\mathrm{P}_{3} \mathrm{~N}_{2}\right)$. Plants grow taller by ensuring that their basic needs includes water, sunlight, warmth and nutrients. By utilizing more nutrients plants grow bigger and healthier. FYM, vermicompost around rhizosphere create the favourable environment to help in better availability and uptake of nutrients by plants. Similar results of increased plant height due to combined application of bio-fertilizer, vermicompost and inorganic fertilizers have been reported by Hemalatha and Suresh (2012), Mishra and Jain (2014) in kamegh. Several research results suggest that plant height depends on stem elongation (Liu et al., 2016; Nagashima and Hikosaka, 2011).

A significant difference was observed on number of branches due to pruning and nutrition levels (Table 1). The maximum number of branches (18.81) was recorded with pruning twice at 6 and 8 weeks after sowing. Application of 100:75:50 NPK ha ${ }^{-1}+$ Vermicompost 2.5t/ha has recorded maximum number of branches (18.48). The interaction effect of pruning and nutrition levels showed significant variation on number of branches.

The maximum number of branches (23.12) was recorded with pruning twice at 6 and 8 weeks after sowing and application of 100:75:50 NPK ha ${ }^{-1}+$ vermicompost 2.5t/ha $\left(\mathrm{P}_{3} \mathrm{~N}_{3}\right)$. The increase in number of branches may be due to increase in number of pruning practice. Pruning thus encourages more number of branches thus increases the herbage yield intern increases seed yield. The number of branches plant ${ }^{-1}$ might depend on the height of the plant which favored formation of more lateral buds, a taller plant yielded a higher number of branches plant ${ }^{-1}$. This phenomenon was also reported by Singh et al., (2011) and Sunil Kumar et al., (2011).

Fresh herbage yield per hectare showed a significant difference due to pruning and nutrition levels (Table 2). The maximum fresh herbage yield (56.82 q/ha) was recorded with pruning twice at 6 and 8 weeks after sowing. 
Table.1 Improvement in the growth and yield of Kalmegh influenced by Pruning and Nutrition levels (2017-2020)

\begin{tabular}{|c|c|c|c|c|c|c|c|c|c|c|c|c|}
\hline \multicolumn{5}{|c|}{ Plant height $(\mathbf{c m})$} & \multicolumn{4}{|c|}{ No. of branches } & \multicolumn{4}{|c|}{ Days to first harvest } \\
\hline & P1 & $\mathbf{P 2}$ & P3 & Mean & P1 & $\mathbf{P 2}$ & P3 & Mean & P1 & $\mathbf{P 2}$ & P3 & Mean \\
\hline N1 & 34.07 & 36.70 & 38.79 & 36.52 & 11.91 & 12.19 & 12.12 & 12.07 & 120.14 & 130.26 & 134.91 & 128.43 \\
\hline N2 & 38.00 & 44.14 & 52.42 & 44.85 & 12.20 & 15.40 & 21.20 & 16.26 & 129.12 & 132.02 & 135.17 & 132.10 \\
\hline N3 & 40.09 & 46.70 & 56.56 & 47.78 & 14.20 & 18.12 & 23.12 & 18.48 & 132.16 & 132.80 & 136.20 & 133.72 \\
\hline Mean & 37.38 & 42.51 & 49.25 & & 12.77 & 15.23 & 18.81 & & 127.14 & 131.69 & 135.42 & \\
\hline Factors & \multicolumn{2}{|c|}{ SE(M)+- } & \multicolumn{2}{|c|}{ C.D at $5 \%$} & \multicolumn{2}{|c|}{ SE(M)+- } & \multicolumn{2}{|c|}{ C.D at 5\% } & \multicolumn{2}{|c|}{ SE(M)+- } & \multicolumn{2}{|c|}{ C.D at $5 \%$} \\
\hline $\mathbf{N}$ & \multicolumn{2}{|c|}{1.71} & \multicolumn{2}{|c|}{3.1} & \multicolumn{2}{|c|}{0.81} & \multicolumn{2}{|c|}{1.21} & \multicolumn{2}{|c|}{3.4} & \multicolumn{2}{|c|}{1.70} \\
\hline $\mathbf{P}$ & \multirow{2}{*}{\multicolumn{2}{|c|}{0.86}} & \multicolumn{2}{|c|}{5.6} & \multicolumn{2}{|c|}{0.46} & \multicolumn{2}{|c|}{2.20} & \multicolumn{2}{|c|}{3.8} & \multicolumn{2}{|c|}{2.42} \\
\hline $\mathbf{N} * \mathbf{P}$ & & & \multicolumn{2}{|c|}{4.8} & \multicolumn{2}{|c|}{1.20} & \multicolumn{2}{|c|}{3.20} & \multicolumn{2}{|c|}{4.2} & \multicolumn{2}{|c|}{1.90} \\
\hline
\end{tabular}

Table.2 Improvement in the growth and yield of Kalmegh influenced by Pruning and Nutrition levels (2017-2020)

\begin{tabular}{|c|c|c|c|c|c|c|c|c|c|c|c|c|}
\hline \multicolumn{4}{|c|}{ Fresh Herbage Yield/ha (q/ha) } & \multicolumn{3}{c|}{ Dry herbage Yield/ ha (q/ha) } & \multicolumn{4}{c|}{ Seed yield/ha (q/ha) } \\
\hline & P1 & P2 & P3 & Mean & P1 & P2 & P3 & Mean & P1 & P2 & P3 & Mean \\
\hline N1 & 41.25 & 46.17 & 44.98 & 44.13 & 15.04 & 17.98 & 17.22 & 16.74 & 1.24 & 1.37 & 1.56 & 1.39 \\
\hline N2 & 48.18 & 51.26 & 60.08 & 53.17 & 18.35 & 19.22 & 21.70 & 19.75 & 1.25 & 1.68 & 1.85 & 1.59 \\
\hline N3 & 49.20 & 57.23 & 65.42 & 57.26 & 18.51 & 20.03 & 23.62 & 20.72 & 1.34 & 1.78 & 1.98 & 1.7 \\
\hline Mean & 46.21 & 51.53 & 56.82 & & 17.3 & 19.07 & 20.84 & & 1.27 & 1.61 & 1.79 & \\
\hline Factors & SE(M)+- & C.D at 5\% & SE(M)+- & C.D at 5\% & SE(M)+- & C.D at 5\% \\
\hline N & 3.20 & 3.80 & 1.36 & 1.30 & 0.76 & 0.95 \\
\hline P & 2.90 & 4.20 & 0.98 & NS & 0.26 & 0.92 \\
\hline N*P & 4.20 & 8.20 & 2.10 & NS & 0.97 & 0.82 \\
\hline
\end{tabular}

Factor I : Pruning $\mathrm{P}_{1^{-}} 0$ Pruning, $\mathrm{P}_{2}$ - Pruning once at 6 weeks after sowing, $\mathrm{P}_{3}$ - Pruning twice at 6 and 8 weeks after sowing

Factor II : Source of Nutrition N1. 75:75:50 NPK ha ${ }^{-1}+$ FYM 10 t/ha

N2. 100:75:50 NPK ha ${ }^{-1}+$ FYM 5 t/ha

N3. 100:75:50 NPK ha ${ }^{-1}+$ Vermicompost $2.5 \mathrm{t} / \mathrm{ha}$

Application of 100:75:50 NPK ha ${ }^{-1}+$ Vermicompost 2.5t/ha has recorded maximum fresh herbage yield $(57.26 \mathrm{q} / \mathrm{ha})$. The interaction effect of pruning and nutrition levels showed significant variation on fresh herbage yield.

The maximum fresh herbage yield (65.42 q/ha) was recorded with pruning twice at 6 and 8 weeks after sowing and application of 100:75:50 NPK ha ${ }^{-1}+$ Vermicompost 2.5t/ha
$\left(\mathrm{P}_{3} \mathrm{~N}_{3}\right)$ which was on par $(57.23 \mathrm{q} / \mathrm{ha})$ with pruning once at 6 weeks after sowing and application of 100:75:50 NPK ha ${ }^{-1}+$ Vermicompost $2.5 \mathrm{t} / \mathrm{ha}\left(\mathrm{P}_{2} \mathrm{~N}_{3}\right)$. Whereas one time and two times of pruning gave higher herbage yield compared to unpruned plants.

The reason for the increased herbage yield might be due to FYM and vermicompost aiding mineralization of immobalized nutrients. These findings are in agreement 
with the results reported by Divya et al., (2017), Hemalatha and Suresh (2012), Sanjutha et al., (2008) in kalmegh.

In case of dry herbage yield, significant difference was shown in nutrition levels (Table 2). The maximum dry herbage yield was recorded in 100:75:50 NPK ha ${ }^{-1}+$ Vermicompost 2.5t/ha $\left(\mathrm{N}_{3}\right) \quad$ whereas significant difference was not shown in case of pruning practice and their interaction.

Seed yield significantly influenced the pruning and nutrition levels (Table 2). The maximum seed yield (1.79 q/ha) was recorded with pruning twice at 6 and 8 weeks after sowing. Application of 100:75:50 NPK ha ${ }^{-1}+$ Vermicompost $2.5 \mathrm{t} /$ ha has recorded maximum seed yield $(1.70 \mathrm{q} / \mathrm{ha})$. The interaction effect of pruning and nutrition levels showed significant variation on seed yield.

The maximum seed yield (1.98 q/ha) was recorded with pruning twice at 6 and 8 weeks after sowing and application of 100:75:50 NPK ha ${ }^{-1}+$ Vermicompost 2.5t/ha $\left(\mathrm{P}_{3} \mathrm{~N}_{3}\right)$ which was on par $(1.78 \mathrm{q} / \mathrm{ha})$ with pruning once at 6 weeks after sowing and application of 100:75:50 NPK ha ${ }^{-1}+$ Vermicompost $2.5 \mathrm{t} / \mathrm{ha}\left(\mathrm{P}_{2} \mathrm{~N}_{3}\right)$. The positive response with the application of FYM, vermicompost due to increased plant growth, increase in number of branches, through improvement in soil conditions and increased availability of nutrients favoured higher seed yields.

From this investigation, the highest fresh herbage yield and seed yield was recorded in the treatment combination of pruning twice at 6 and 8 weeks after sowing and application of 100:75:50 NPK ha ${ }^{-1}+$ Vermicompost 2.5t/ha $\left(\mathrm{P}_{3} \mathrm{~N}_{3}\right)$. From the above results, it may be stated that the practice of pruning and use of chemical fertilizers along with vermicompost in integrated manner is beneficial in improving the growth of kalmegh.

\section{References}

Akbar S. 2011. Andrographis paniculata: a review of pharmacological activities and clinical effects. Altern Med Rev.16(1):66-77.

Arpana J, Bagyaraj DJ. 2007. Response of Kalmegh to an arbuscular mycorrhizal fungus and a plant growth promoting rhizomicroorganism at two levels of phosphorus fertilizer. AmericanEurasian J Agric Environ Sci. 2(1):3338.

Calatayud A, Roca D, Gorbe E. Martynez PF (2008). Physiological effects of pruning in rose plants cv. Grand Gala. Scientia Horticultural. 116: 73-79.

Chakravarti D, Chakravarti RN. Andrograpolide. Indian Journal of Chemical Society. 1952, 1697.

Divya Bhargavi D, Madhavi Lata A and Srinivas A. Influence of INM Practices on Overall Growth, Yield and Economics of Andrographis paniculata (Kalmegh) in Pongamia Based Agri-Silvi System. Int.J.Curr.Microbiol.App.Sci (2017). 6(10): 698-706.

Hemalatha P, Suresh J. Impact of integrated nutrients on growth and yield of kalmegh (Andrographis paniculata). International Journal of Agricultural Sciences. 2012; 8:168-170.

Jarukamjorn K, Nemoto N. 2008. Pharmacological aspects of Andrographis paniculata on health and its major diterpenoid constituent andrographolide. J Health Sci. 54(4):370-381.Kumar A, Dora J, Singh A, Tripathi R. 2012. A review on king of bitter (Kalmegh). Int $\mathbf{J}$ Res Pharm Chem. 2(1):116-124.

Kumar A, Dora J, Singh A, Tripathi R. 2012. A review on king of bitter (Kalmegh). Int J Res Pharm Chem. 2(1):116-124. 
Liu, H., C. Yang and L. Li (2016). Shadeinduced stem elongation in rice seedlings: Implication of tissuespecific phytohormone regulation. Journal of Integrative Plant Biology, 58(7): 614-617.

Mishra S, Jain A. Effect of INM on vegetative growth, flowering and fruiting of Andrographis paniculata. Journal of Agricultural Research. 2014: 2(3):9396.

Moktader IA, Sirchar GSS. The bitter principle from Andrographis paniculata. J Indian Chemica Society. 1939; 16:333-338.

Nagashima, H. and K. Hikosaka (2011). Plants in a crowded stand regulate their height growth so as to maintain similar heights to neighbours even when they have potential advantages in height growth. Annals of Botany, 108: 207214.

Nishchitha M, Hiremath JS, Gireesh Ankad, Mahantesh PS, Pooja MR and Lokesh CH. 2018. Effect of integrated nutrient management on yield and quality of kalmegh (Andrographis paniculata Nees.). Journal of Pharmacognosy and Phytochemistry. SP3: 122-125.

Patidar S, Gontia AS, Upadhyay A, Nayak PS. 2011. Biochemical constituents in Kalmegh (Andrographis paniculata Nees) under various row spacing's and nitrogen levels. World Appl Sci J. 15(8):1095-1099.

Randa SS, Sharma A. Hepatoprotective activity of andrographolide from
Andrographis paniculata against carbon tetrachloride. Indian Journal of Medical Research. 1990; 92(4):276283.

Sanjutha S Subramanian S Rani I. and Maheswari J. Integrated nutrient management in Andrographis paniculata. Res. J. Agri. and Biological Sci., 2008; 4 (2): 141-145.

Singh, M., A. Singh, A.S. Tripathi, R.K. Verma, M.M. Gupta, H. O. Mishra, H.P. Singh and A.K. Singh (2011). Growth behavior, biomass and diterpenoid lactones production in Kalmegh (Andrographis paniculata Nees.) strains at different population densities. Agricultural Journal, 6(3): 115-118.

Sunil Kumar, B.V., A. Kumar and M. Kataria (2011). Effect of heat stress in tropical livestock and different strategies for its amelioration. Journal of Stress Physiology \& Biochemistry, 7(1): 4554.

Yilmaz G, Kandemir N, Kinalioglu K (2004). Effects of different pruning intervals on fresh shoot yield and some quality properties of tea (Camellia sinensis $\mathrm{L}$. Kuntze) in Turkey. Pakistan Journal of Biological Sciences, 7: 1208-1212.

Zeing B (2003). Functional equilibrium between photosynthetic and above ground non photosynthetic structures of plants: Evidence from a pruning experiment with three subtropical tree species. Acta Botanica Sinica. 45: 152157.

\section{How to cite this article:}

Cheena, J., V. Krishna Veni, M. Padma and Sreenivas, M. 2020. Improvement in the Growth and Yield of Kalmegh influenced by Pruning and Nutrition levels. Int.J.Curr.Microbiol.App.Sci. 9(12): 3569-3574. doi: https://doi.org/10.20546/ijcmas.2020.912.424 